Volume VI , Nomor 2, Desember 2020 : Hal 182-192

Jurnal Utile

https://jurnal.ummi.ac.id/index.php/JUT

\title{
STRATEGI SISWA “EXTROVERT" DALAM MEMPELAJARI KETERAMPILAN BERBICARA BAHASA INGGRIS
}

\author{
Ummi Qalsum Arif \\ Program Studi Pendidikan Bahasa Inggris/Institut Keguruan dan Teknologi Larantuka \\ Jln. Ki Hajar Dewantara-Larantuka 8621-Flores Timur \\ ummiarif29@gmail.com
}

\begin{abstract}
Abstrak: Berbicara adalah salah satu keterampilan yang paling diprioritaskan untuk dikuasai oleh siswa karena mereka akan lebih mudah memahami materi dan mereka akan lebih mudah untuk menanyakan sesuatu dalam bahasa Inggris ketika merasa bingung. Faktanya, para guru dan siswa perlu lebih berhati-hati dalam beberapa faktor internal yang mungkin mempengaruhi siswa dalam menguasai bahasa Inggris. Keberhasilan pembelajaran berbicara tidak selalu bergantung pada strategi yang diterapkan oleh guru di kelas, Namun keberhasilannya juga berpengaruh besar dari strategi yang digunakan siswa dalam pembelajaran berbicara. Salah satu faktor internal yang dapat mengganggu penguasaan berbicara siswa adalah kepribadian. Ekstrovert memiliki pengaruh terbesar dalam pembelajaran bahasa terutama dalam meningkatkan keterampilan berbicara. Tujuan dari penelitian ini adalah untuk mengetahui strategi yang digunakan oleh siswa ekstrovert dalam pembelajaran keterampilan berbicara. Desain penelitian yang digunakan dalam penelitian ini adalah penelitian kualitatif deskriptif. Subjek penelitian ini adalah lima siswa ekstrovert di International Class Program (ICP) kelas XI SMA Laboratorium UM. Alat tes kepribadian, catatan observasi lapangan, dan wawancara tidak terstruktur digunakan untuk mengumpulkan dan menganalisis data. Hasil penelitian menunjukkan bahwa sebagian besar siswa ekstrovert menggunakan strategi Kognitif, Meta kognitif dan Sosial dalam mempelajari kemampuan berbicara. Selain itu, dalam strategi kognitif dan sosial, siswa ekstrovert selalu berbicara bahasa Inggris dengan orang yang mereka temui dan mereka merasa nyaman untuk berbicara bahasa Inggris dengan banyak orang di sekitar mereka.
\end{abstract}

Kata Kunci: strategi, berbicara, kepribadian, ekstrovert

Abstract: Speaking becomes the most priority skill to be able mastered by the students because they will be easier to understand about the material and they will get easier to ask something in English when they get confuse. In the fact, the teachers and the students need to be more carefully in some internal factors that may affect students in acquiring English. The successful in learning speaking do not always depend on strategies implemented by the teacher in the classroom, but its successful is also have big influence from the strategies used by the students in learning speaking. One of the internal factors that may disturb students' mastery in speaking is personality. Extrovert has biggest influence in learning language especially in increasing speaking skill. The purposes of the study were to know the strategies used by Extrovert students in learning speaking skill. The research design used in this study was a descriptive qualitative research. The subjects of this research were ten Extrovert students in International Class Program (ICP) - tenth Grader in SMA Laboratorium UM. Personality inventory, observation field notes, and unstructured interview were used to collect and analyzed the data. The result of this study showed that mostly Extrovert students use Cognitive, Metacognitive and Social strategies in maintaining their speaking ability. Besides, in cognitive and social strategy, Extrovert speak English as often as possible with any people they meet to and they feel comfort to talk English with many people around them

Keywords: strategy, speaking, personality, extrovert

History :

Submit tgl 7 Desember 2020, revisi 7 Desember 2020, diterima 7 Desember 2020 


\section{PENDAHULUAN}

Keterampilan berbicara menjadi hal yang sangat penting dalam proses belajar mengajar karena akan memudahkan siswa dalam memahami materi. Hal ini dikaenakan, kemampuan berbicara akan membantu mereka untuk menanyakan sesuatu dalam bahasa Inggris ketika mereka tidak dapat memahami penjelasan gurunya. Namun, guru dan siswa perlu lebih berhati-hati dalam beberapa faktor internal yang dapat mempengaruhi siswa dalam mempelajari bahasa Inggris karena pembelajar bahasa yang dikatakan berhasil apabila menguasai bahasa kedua. Lightbown dan Spada (1999) menyatakan bahwa terdapat beberapa faktor yang mempengaruhi pembelajaran bahasa kedua yang termasuk dalam karakteristik peserta didik seperti kecerdasan, bakat, kepribadian, motivasi dan sikap, preferensi peserta didik, keyakinan peserta didik dan usia perolehan. Kepribadian menjadi faktor krusial dalam mempelajari kemampuan berbicara siswa. Kepribadian dan kemahiran bahasa dapat mempengaruhi pemikiran, keputusan, tindakan, dan pola komunikasi seseorang (Chew dan $\mathrm{Ng}$, 2016). Memiliki kepribadian yang berbeda dapat mempengaruhi cara siswa belajar kemampuan berbicara. Nyatanya, tidak semua siswa mampu bersuara di depan banyak orang karena memiliki kepribadian yang berbeda.

Ekstrovert memiliki pengaruh terbesar dalam pembelajaran bahasa terutama dalam meningkatkan keterampilan berbicara. Ekstrovert cenderung memberikan kinerja terbaik dalam pembelajaran aktif (Alwisol, 2009). Dengan kata lain, terdapat interaksi antara kepribadian dan strategi pembelajaran yang perlu diwaspadai oleh siswa untuk memperoleh efektivitas pembelajaran bahasa. Zhang (2008) menyatakan bahwa orang ekstrovert lebih tertarik untuk mengetahui apa yang terjadi di sekitarnya daripada pikiran dan emosinya sendiri. Selain itu, seorang ekstrovert yang supel dan blak-blakan dapat mempelajari bahasa target dengan lebih mudah karena dia lebih antusias dalam menggunakan bahasa tersebut dan kurang peduli akan membuat kesalahan (Chew dan Ng, 2016).

Keterkaitan antara kepribadian dan pembelajaran bahasa asing memberikan kesimpulan yang jelas bahwa terdapat pengaruh yang besar antara kepribadian ekstrovert dengan strategi siswa dalam mempelajari keterampilan berbicara khususnya berbicara Bahasa Inggris. Fatahi et al (2016) percaya bahwa strategi belajar peserta didik bergantung pada 
kepribadiannya. Oleh karena itu, individu dengan kepribadian yang berbeda memiliki strategi pembelajaran khusus

\section{METODOLOGI PENELITIAN}

Dalam penelitian ini, peneliti menggunakan desain penelitian kualitatif deskriptif untuk mengidentifikasi strategi berbicara yang digunakan oleh siswa ekstrovet. Penelitian dilakukan di kelas X Program Kelas Internasional di SMA LABORATORIUM UM tahun ajaran 2019/2020 dimana siswanya belajar bahasa Inggris sebagai bahasa asing. Kelas ini memiliki total siswa sebanyak 17. Akan tetapi, subjek penelitian nya adalah 5 siswa ekstrovert dimana 5 siswa tersebut dipilih karena kemampuan berbahasa Inggrisnya yang baik. Adapun, dalam penelitian ini, peneliti menjadi pengamat non-partisipatif

Dalam menentukan kepribadian siswa kategori Extrovert, peneliti membagikan inventaris kepribadian atau alat tes kepribadian kepada 17 siswa di kelas. Inventarisasi kepribadian diadopsi dari MBTI (Myers-Briggs Type Indicator) yang diambil dari Laboratorium Psikologi UMM. Dalam inventarisasi kepribadian ini terdapat beberapa pilihan kegiatan ekstrovert dan introvert dan siswa diharapkan memilih satu kegiatan yang mereka sukai dari masing-masing pilihan. Ada 11 kegiatan dalam mempelajari keterampilan berbicara bahasa Inggris.

untuk ekstrovert dan 11 kegiatan untuk kategori introvert yang selayaknya dipilih oleh siswa. Misalnya, jika seorang siswa memilih opsi "Memiliki ulang tahun", itu berarti siswa tersebut dikategorikan menjadi ekstrovert, dan seterusnya. Jika siswa lebih memilih kegiatan ekstrovert daripada introvert, berarti siswa dapat dikategorikan ekstrovert karena memiliki kriteria ekstrovert yaitu mudah bergaul dengan orang lain, penyayang, aktif berbicara, menyenangkan dan sangat antusias.

Selain itu, terdapat beberapa kriteria untuk menentukan kemampuan berbahasa Inggris siswa, yang menjadi pertimbangan peneliti dalam memilih 5 subjek penelitian,yakni : 1) 5 subjek penelitian adalah siswa kelas Internasional yang artinya sudah familiar dengan mata pelajaran berbicara dan sudah pernah menggunakan atau berpengalaman dalam belajar strategi berbicara.; (2) Para siswa juga menjadi calon sekolah untuk mengikuti beberapa perlombaan bahasa Inggris seperti debat, pidato, atau bahkan story telling yang menunjukkan bahwa mereka memiliki pengetahuan bahasa Inggris yang cukup. Oleh karena itu, diasumsikan bahwa 
mereka secara alami memiliki strategi khusus dalam pembelajaran bahasa Inggris khususnya berbicara; (3) Mereka juga memilih jurusan bahasa Inggris untuk melanjutkan studi di tingkat universitas karena mereka berpikir sangat penting untuk memiliki kemampuan berbahasa Inggris ketika ingin mendapatkan beasiswa di luar negeri.. Hal tersebut menunjukkan bahwa penggunaan strategi pembelajaran sangat dianjurkan bagi mereka dalam meningkatkan keterampilan berbicara bahasa Inggris.

Seleksi siswa juga dilakukan melalui percakapan dengan 17 siswa untuk mengetahui kemampuan berbahasa Inggris siswa. Setelah peneliti menentukan 5 siswa yang masuk kategori fasih berbicara, peneliti memvalidasi hasil seleksi siswa yang fasih verbicara bahasa Inggris dengan guru untuk memastikan hasil yang ditemukan adalah valid. Setelah itu, 5 siswa yang termasuk dalam kategori siswa ekstrovert dibawa ke psikolog untuk verifikasi hasil tes kepribadian. Psikolog diminta untuk meyakinkan peneliti bahwa 5 siswa sebagai subjek dalam penelitian ini adalah valid sebagai sampel ekstrovert.

Penelitian ini melakukan triangulasi untuk menghindari subjektivitas data. Triangulasi dilakukan dengan observasi, inventarisasi kepribadian, dan wawancara dengan subjek penelitian dimana penelitian ini difokuskan pada siswa ekstrovert kelas X International Class Program (ICP). Setelah melakukan validasi data, pneliti melanjutkan analisis data sebelum akhirnya menarik kesimpulan penelitian.

Pengumpulan data dilakukan dengan teknik kualitatif yaitu observasi kelas dan wawancara mendalam untuk memperoleh data verbal dan non verbal dari subjek penelitian. Dalam proses pengumpulan data, peneliti juga menggunakan beberapa instrumen penelitian seperti inventarisasi kepribadian, catatan lapangan, pedoman wawancara dan alat perekam video yang diharapkan dapat membantu peneliti dalam mendapatkan hasil yang mendalam berupa gambaran tentang seluruh peristiwa yang terjadi selama proses kegiatan belajar berbicara bahasa Inggris di kelas.

Setelah peneliti mengumpulkan data, peneliti menginterpretasikan datadata tersebut dari hasil catatan lapangan, wawancara dan rekaman video untuk mengetahui strategi yang digunakan oleh siswa ekstrovert dalam belajar berbicara. Kemudian, peneliti mengklasifikasikan dan mengkategorikan strategi yang digunakan oleh para siswa ini berdasarkan Strategy Inventory Language 
Learning (SILL) versi 7.0 yang menampilkan strategi pembelajaran umum. Penelitian kali ini hanya berfokus pada strategi berbicara, sehingga peneliti perlu memastikan strategi yang mereka gunakan dalam belajar berbicara dengan hasil wawancara mendalam bersama ke 5 siswa extrovert. Akhirnya, peneliti menarik kesimpulan berdasarkan seluruh informasi yang diperoleh dari observasi catatan lapangan, pedoman wawancara dan rekaman video.

\section{HASIL PENELITIAN DAN}

\section{PEMBAHASAN}

Berdasarkan data perbandingan antara observasi dan wawancara yang telah dijelaskan di atas, Siswa pertama yaitu si D banyak menggunakan strategi kognitif, metakognitif dan sosial dalam belajar berbicara bahasa Inggris. Hal ini terbukti dari aktivitas yang dilakukannya untuk semakin lancar berbicara dengan menggunakan strategi-strategi tersebut. Dalam strategi kognitif, ia mencoba berbicara dalam bahasa Inggris seperti penutur asli agar selalu mengingat aksen Australianya, Dia juga menambahkan bahwa terkadang dia berbicara dalam bahasa Inggris dengan guru atau teman seperti ketika mereka menggunakan bahasa Inggris dengannya, dia melatih bunyi dari sebuah kata bahasa Inggris baru terutama kata-kata baru yang dia dapatkan dari lagu-lagu barat yang ia sering dengarkan, dia mencoba merangkum informasi yang dia dapatkan dari film atau game baru.

Dalam strategi metakognitif, ia tetap memperhatikan guru dan juga teman-temannya berbicara jika ada topik menarik yang disampaikan oleh mereka dan Ia akan bertemu kembali dengan gurunya dan juga teman-temannya untuk mendiskusikan topik tersebut jika ia membutuhkan lebih banyak informasi tentang topik tertentu. Dalam strategi sosial, ia mencoba berlatih bahasa Inggris sesering mungkin dengan temantemannya, dia mencoba untuk bertanya dalam bahasa inggris kepada gurunya atau teman-temannya seperti ketika dia lupa kata bahasa indonesia dari sebuah kata yang sering diucapkan dalam Bahasa Ingris dan meskipun dia menghabiskan masa kecilnya di Australia tetapi dia tetap meminta pembicara untuk memperlambat atau mengatakannya lagi ketika mereka berbicara.

Sedangkan dalam memori, kompensasi, dan strategi afektif, D hanya menggunakan sedikit jenis strategi tersebut dalam belajar berbicara seperti dalam strategi memori, dia teringat kata bahasa Inggris baru dengan membayangkan gambar, dia menggunakan gestur ketika dia berbicara dalam bahasa Inggris dan dia mencoba 
menebak apa yang dikatakan pembicara terutama di seminar atau konferensi dan dalam strategi afektif dia akan lebih santai ketika berbicara dalam bahasa Inggris.

Siswa kedua A kebanyakan menggunakan strategi kognitif, metakognitif, memori dan sosial dalam belajar berbicara bahasa Inggris. Hal itu terbukti dari aktivitas yang dilakukannya untuk lebih fasih berbahasa dengan menggunakan strategi-strategi tersebut. Dalam strategi kognitif, si A mencoba berbicara bahasa Inggris seperti penutur asli dan sering mencoba memahami orang asing berbicara bahasa Inggris sehingga dia bisa memahami yang dibicarakan oleh penutur asli dan dia bisa menjawab semua pertanyaan yang disampaikan oleh mereka, Dia berbicara dengan teman-temannya tentang permainan dan dia juga mencoba untuk berbicara dengan gurunya dalam bahasa Inggris jika dia ingin mendiskusikan beberapa materi sulit yang belum dimengerti, dia juga menggunakan waktunya untuk melatih pengucapan kata-kata bahasa Inggris baru yang dia dapatkan di sekolah atau di luar sekolah, Ia menonton film dengan subtitle bahasa Inggris, dan ia juga merangkum semua informasi atau cerita yang ia dapat dari game, film, atau buku.
Dalam strategi metakognitif, Ia memperhatikan ketika gurunya dan juga teman-temannya berbicara dalam bahasa Inggris dan ia berusaha menemui gurunya untuk menanyakan berbagai macam topik yang dapat ia diskusikan dengan guru atau teman-temannya di kelas maupun di luar kelas. Dalam strategi memori, dia menggunakan katakata bahasa Inggris dalam kalimat ketika dia berkomunikasi dengan temantemannya di sekolah, dia juga berlatih berbicara dengan kata-kata bahasa Inggris baru yang dia tahu dari film, game atau bahkan dari buku dan dia mengingat kata-kata bahasa Inggris baru ketika melihatnya gambaran mental.

Dalam strategi sosial, dia bertanya kepada teman-temannya yang lebih ahli dari dia dan gurunya untuk mengoreksinya ketika dia berbicara dalam bahasa Inggris, dia berlatih berkomunikasi dalam bahasa Inggris dengan teman-temannya, dia banyak bertanya kepada guru dan temantemannya untuk sesuatu yang membuatnya tertarik. Bahkan, A jarang menggunakan kompensasi dan strategi afektif seperti dalam strategi kompensasi, dia hanya menggunakan gestur ketika berbicara dalam bahasa Inggris dan dalam strategi afektif, dia mencoba untuk rileks dan mendorong dirinya untuk berbicara dalam bahasa Inggris. 
Siswa ketiga yaitu Ag banyak menggunakan strategi kognitif, afektif, dan sosial dalam belajar berbicara. Hal itu terbukti dari aktivitas yang dilakukannya untuk lebih fasih berbahasa Inggris dengan menggunakan strategistrategi tersebut. Dalam strategi kognitif, dia berbicara dalam bahasa Inggris seperti penutur asli dengan mulai berbicara terlebih dahulu dalam bahasa Inggris dengan guru atau temantemannya, dia melatih buni kata-kata bahasa Inggris baru untuk membuatnya terbiasa dengan kata-kata baru itu dan dia juga sering menonton film menggunakan subtitle bahasa Inggris saat di rumah. Dalam strategi afektif, ia mencoba untuk rileks ketika berbicara dalam bahasa Inggris, dia berusaha untuk mendorong dirinya sendiri untuk berbicara dalam bahasa Inggris dan dia juga mencoba untuk menceritakan perasaannya dala bahasa Inggris kepada sahabatnya untuk berlatih berkomunikasi dalam bahasa Inggris. Dalam strategi Sosial, dia meminta teman-temannya untuk mengoreksinya ketika dia melakukan kesalahan dalam berbicara bahasa Inggris, dia meminta pembicara untuk berbicara lambat atau mengatakannya lagi ketika sedang berkomunikasi atau ketika dia tidak mengerti apa yang mereka katakan dalam bahasa Inggris, dia pun berlatih bahasa Inggris dengan teman-temannya dengan caranya sendiri yang menurutnya nyaman seperti mengobrol via whatssap dan dia pun sering mengajukan pertanyaan dalam bahasa Inggris kepada guru atau temannya untuk sesuatu yang belum di mengerti. Strategi memori, kompensasi, dan metakognitif jarang digunakan oleh Ag karena dalam strategi memori, ia hanya memberikan informasi bahwa ia mereview pelajaran sebelum kelas dimulai, dalam strategi kompensasi, dia mengatakan bahwa dia menggunakan isyarat ketika dia berbicara dalam bahasa Inggris dan dia menebak apa yang dikatakan pembicara selanjutnya dalam bahasa Inggris, Dalam strategi metakognitif, dia hanya mengatakan dia memberikan konsentrasi penuh ketika guru atau teman-temannya berbicara dalam bahasa Inggris.

Siswa keempat adalah $\mathrm{S}$ yang paling banyak menggunakan strategi kognitif, metakognitif, dan sosial dalam belajar berbicara. Terbukti dari aktivitasnya yang ia lakukan membuatnya lebih lancar berbicara dengan menggunakan strategi-strategi tersebut. Dalam strategi kognitif, dia sering meniru aksen penutur asli, dia juga mencoba berbicara dalam bahasa Inggris dengan guru dan teman-temannya agar bahasa Inggrisnya lebih lancar, dan dia menonton film berbahasa Inggris tanpa 
subtitle tapi terkadang dia juga menggunakan subtitle bahasa Inggris.

Dalam strategi metakognitif, ia memperhatikan ketika gurunya atau juga teman-temannya berbicara dalam bahasa inggris, dan dia berusaha untuk bertemu dengan guru atau juga teman-temannya untuk berbicara dalam bahasa inggris baik di kelas bahasa inggris ataupun diluar kelas Bahasa Inggris. Dalam strategi sosial, dia meminta penutur asli untuk memperlambat atau mengatakannya lagi pada beberapa kalimat tertentu yang tidak di mengerti, dia berlatih bahasa Inggris dengan temantemannya, dan dia mengajukan pertanyaan dalam bahasa Inggris kepada guru dan teman-temannya ketika dia merasa bingung dalam belajar bahasa Inggris. Dalam hasil penelitian ini, $S$ jarang menggunakan memori, kompensasi dan afektif terutama dalam strategi kompensasi, dia tidak pernah mencoba melakukannya dan dalam strategi memori, S hanya mempraktikkan kata-kata bahasa Inggris yang baru dia ketahui dan ia mencoba mengingat katakata bahasa Inggris baru dengan membayangkan gambar dari kata tersebut, dan yang terakhir dalam strategi afektif, dia berkata bahwa dia cukup dengan santai ketika berbicara dalam bahasa Inggris.
Siswa kelima adalah Sy yang paling banyak menggunakan strategi kognitif, memori, afektif dan sosial dalam belajar berbicara. Terbukti dari aktivitasnya yang ia lakukan membuatnya lebih lancar berbicara dengan menggunakan strategi-strategi tersebut. Dalam strategi kognitif, dia mencoba berbicara bahasa Inggris seperti penutur asli untuk mencoba aksen yang berbeda, dia juga berbicara dengan guru atau teman dalam bahasa Inggris dan dia pun menonton film menggunakan subtitle bahasa Inggris tetapi kadang-kadang dia tidak menggunakan subtitle sama sekali.

Dalam strategi memori, dia mempraktikkan kata-kata bahasa Inggris yang dia baru ia ketahui, dan dia bisa mengingat kata bahasa Inggris baru dengan membayangkan gambar dari kata tersebut. Dalam strategi afektif, dia mencoba untuk rileks ketika dia berbicara dalam bahasa Inggris dan dia berusaha untuk selalu mendorong dirinya sendiri untuk berbicara dalam bahasa Inggris bahkan dia takut melakukan kesalahan. Dalam strategi sosial, dia meminta pembicara untuk memperlambat atau mengatakannya lagi terutama untuk penutur asli jika dia tidak mengerti atau jika mereka berbicara terlalu cepat dan Dia berlatih bahasa Inggris dengan teman-temannya yang benar-benar 
memiliki kemampuan berbahasa Inggris yang baik.

Sebenarnya, Sy jarang menggunakan strategi kompensasi dan metakognitif berdasarkan hasil penelitiannya. Dalam strategi kompensasi, dia hanya mengatakan bahwa dia menggunakan gerakan seperti dia menggerakkan tangannya ketika dia berbicara dalam bahasa Inggris dan dalam strategi metakognitif, dia juga hanya mengatakan bahwa dia memperhatikan guru atau teman ketika mereka berbicara dalam bahasa Inggris dengannya.

Penelitian ini berfokus pada strategi berbicara siswa yang hanya terbatas untuk ekstrovert. SILL (Strategy Inventory for Language Learning) versi 7.0 oleh Oxford (1990), terdapat enam macam strategi langsung dalam pembelajaran bahasa yaitu (1) Strategi Memori (mengingat dan mengambil kosakata), yaitu bagaimana pelajar mengingat dan mempertahankan bahasa; (2) Strategi kognitif (memahami dan menghasilkan teks), yang menunjukkan bagaimana peserta didik memikirkan pembelajaran mereka; dan (3) Strategi kompensasi (mengkompensasi kurangnya pengetahuan), yang mencerminkan bagaimana pelajar membuat bahasa yang terbatas untuk mencapai penggunaan bahasa yang berhasil dan strategi tidak langsung termasuk (4) Strategi metakognitif (memanipulasi proses pembelajaran), yaitu bagaimana mereka mengelola pembelajaran mereka sendiri; (5) Strategi afektif (mengatur keadaan afektif) atau bagaimana peserta didik menyesuaikan status afektifnya dalam proses pembelajaran; (6) Strategi sosial (belajar dengan orang lain) yang mengacu pada bagaimana peserta didik mempelajari bahasa melalui interaksi sosial. Penelitian ini menggunakan SILL versi 7.0 untuk menganalisis strategi yang digunakan oleh siswa ekstrovert dalam belajar berbicara bahasa Inggris.

Selama proses analisis data, dilakukan triangulasi dan hasilnya menunjukkan bahwa sebagian besar siswa ekstrovert cenderung menghabiskan waktunya untuk menggunakan strategi kognitif, metakognitif dan sosial dalam mendukung mereka dalam belajar berbicara bahasa Inggris. O'Malley dan Chamot (1990) mengusulkan strategi pembelajaran L2 seperti metakognitif yang menggunakan advance organizer, selective attention, self-management, functional planning, self-monitoring dan self-management, Kognitif yang menggunakan pencatatan, perumpamaan, kata kunci, kontekstualisasi, latihan, dan inferensi, dan sosial yang menggunakan 
kerja sama dan pertanyaan untuk klarifikasi. Artinya, siswa ekstrovert cenderung menggunakan strategi kognitif, metakognitif, dan sosial karena mereka memiliki kemampuan untuk mengatur pembelajarannya sendiri, mereka dapat berlatih berbicara kapan pun mereka perlu, dan mereka memiliki kemauan untuk belajar dengan orang lain sebagai cara mereka dalam mempelajari keterampilan berbicara. Suliman (2014) menambahkan bahwa sebagian besar siswa ekstrovert mudah berkomunikasi di kelas bahasa Inggris atau di luar kelas walaupun mereka tidak yakin dengan jawaban mereka, mereka akan berhasil. Oleh karena itu, siswa ekstrovert cenderung menggunakan strategi kognitif, metakognitif, dan sosial karena memiliki kemampuan bersosialisasi dengan banyak orang, Mereka sangat cepat dalam berpikir, mereka juga optimis dalam mencapai sesuatu, dan mereka juga orang yang impulsif karena mereka cenderung melakukan sesuatu berdasarkan keinginannya dan mereka bersemangat untuk melakukan sesuatu yang membuat mereka bahagia (Eyesenk \& Eysenk, 1969). Hal ini menunjukan bahwa siswa extrovert memiliki kemampuan belajar berbicara bahasa Inggris yang baik.

\section{Kesimpulan}

Berdasarkan temuan penelitian, dapat disimpulkan bahwa siswa ekstrovert lebih banyak menggunakan strategi kognitif, metakognitif dan sosial dalam pembelajaran berbicara bahasa Inggris. Siswa ekstrovert menerapkan strategi kognitif dan sosial kepada semua teman atau gurunya tanpa merasa tidak aman atau malu untuk bertanya atau berlatih bahasa Inggris dengan semua teman dan guru yang memiliki kemampuan berbahasa Inggris yang baik di sekolah atau teman dan guru yang ada di luar sekolah. Dalam strategi metakognitif, siswa cenderung memiliki rencana untuk mengelola pembelajarannya sendiri seperti mereka selalu bertemu dengan guru atau temantemannya untuk mendiskusikan sesuatu dalam bahasa Inggris atau sekedar bertanya kepada teman atau gurunya ketika mereka mendapat masalah dalam belajar bahasa Inggris.

Sebenarnya penelitian kali ini mencoba untuk mengidentifikasi strategi yang digunakan oleh siswa ekstrovert dengan mempertimbangkan kemampuan bahasa mereka. Mahasiswa harus fasih berbicara karena tujuan dari penelitian ini adalah untuk meyakinkan masyarakat bahwa strategi yang digunakan oleh mahasiswa ekstrovert dalam penelitian ini dapat merepresentasikan strategi keseluruhan siswa ekstrovert. Oleh 
karena itu, hasil penelitian ini sangat berguna untuk melengkapi hasil penelitian sebelumnya yang masih belum fokus pada strategi siswa ekstrovert dengan melihat kemampuan berbahasa Inggris yang baik dalam pembelajaran keterampilan berbicara.

\section{Daftar Pustaka}

Alwisol. (2009). "PsikologiKepribadian (EdisiRevisi)”. Malang: UMM Press

Asmali, Mehmet. (2014). “The Relationship Between the Big Five Personality Traits and Language Learning Strategies ".Journal of Social Sciences Institute. Vo. 17, No. 32 : $1-18$

Chew, S.Y, and Ng, L.L. (2016). "The Relevance of Personality and Language Proficiency on the Participation Style of ESL Learners in Face-to-Face and Online Discussions". Springer Journal. Vol. 5, Issue 4 : 605-613

Eysenck, H. J., \&Eysenck, S. B. G. (1969)."Manual of the Eysenck Personality Inventory". London: Hodder\& Stoughton

Fatahi, S, Moradi, H, and Kashani-Vahid, L. (2016). "A Survey of Personality and Learning Styles Models Applied in Virtual Environments with Emphasis on E-Learning Environments. Springer Journal. Vol. 46, Issue 3 : 87-931

Fazeli, S.H. (2012)."The Relationship between the Extraversion Trait and Use of the English Language Learning Strategies".Indian Journal of Science and
Technology. Vol.5, No.4 : 26512657.

Lightbown, Pasty, M., and Spada, Nina. (1999). "How Language are Learned (Second Edition)". Oxford: Oxford University Press

O’Malley, J. M. \& A. U. Chamot. (1990). "Learning Strategies in Second Language Acquisition".

Cambridge UK: Cambridge University Press.

Oxford, R.L. (2011). "Strategies for Learning Second or Foreign Language”. Cambridge University Journal. Vol. 44, Issue 02 : 167180

Saville-Troike, M. 2006. "Introducing Second Language Acquisition”. New York: Cambridge University Press.

Suliman, F. (2014). "The Role of Extrovert and Introvert Personality in Second Language Acquisition". (Online), (http://www.ocerint.org/Sociont1 4 _ebook/papers/xx01.pdf), retrieved 27 March, 2018.

Zhang, Yan. (2008). " The Role of Personality in Second Language Acquisition". Asian Social Science. Vol. 4, No. 5 : 58-59 